\title{
Applications of Artificial Intelligence in Agriculture: A Review
}

\author{
Ngozi Clara Eli-Chukwu \\ Department of Electrical \& Electronics Engineering \\ Alex Ekwueme Federal University Ndufu Alike, \\ Ebonyi, Nigeria \\ ngozieli@gmail.com
}

\begin{abstract}
The application of Artificial Intelligence (AI) has been evident in the agricultural sector recently. The sector faces numerous challenges in order to maximize its yield including improper soil treatment, disease and pest infestation, big data requirements, low output, and knowledge gap between farmers and technology. The main concept of $A I$ in agriculture is its flexibility, high performance, accuracy, and cost-effectiveness. This paper presents a review of the applications of $A I$ in soil management, crop management, weed management and disease management. A special focus is laid on the strength and limitations of the application and the way in utilizing expert systems for higher productivity.
\end{abstract}

Keywords-artificial intelligence; agriculture; soil management; crop management; disease management; weed management; yield

\section{INTRODUCTION}

Agriculture is the bedrock of sustainability of any economy [1]. It plays a key part in long term economic growth and structural transformation [2-4], though, may vary by countries [5]. In the past, agricultural activities were limited to food and crop production [6]. But in the last two decades, it has evolved to processing, production, marketing, and distribution of crops and livestock products. Currently, agricultural activities serve as the basic source of livelihood, improving GDP [7], being a source of national trade, reducing unemployment, providing raw materials for production in other industries, and overall develop the economy [8-10]. With the global geometric population rise it becomes imperative that agricultural practices are reviewed with the aim of proffering innovative approaches to sustaining and improving agricultural activities. The introduction of AI to agriculture will be enabled by other technological advances, including big data analytics, robotics, the internet of things, the availability of cheap sensors and cameras, drone technology, and even wide-scale internet coverage on geographically dispersed fields. By analyzing soil management data sources such as temperature, weather, soil analysis, moisture, and historic crop performance, AI systems will be able to provide predictive insights into which crop to plant in a given year and when the optimal dates to sow and harvest are in a specific area, thus improving crop yields and decrease the use of water, fertilizers, and pesticides. Via the application of AI technologies the impact on natural ecosystems can be reduced, and worker safety may increase, which in turn will keep food prices down and ensure that the food production will keep pace with the increasing population.

\section{CONSIDERATION OVERVIEW}

Farming entails a great deal of choices and uncertainties. From season to season the weather varies, the prices of farming materials fluctuate, soil degrades, crops are not viable, weeds suffocate crops, pests damage crops, and the climate changes. Farmers must cope with these uncertainties. Although agricultural practice is broad, this research considers soil, crop, disease and weeds as major contributors to agricultural production. It is paramount to review the application of AI to agriculture in respect to soil, crop, diseases and pest management.

- Soil is a critical part of successful agriculture and is the original source of the nutrients used to grow crops. Soil is the basis of all production systems in agriculture, forestry and fishery. Soil stores water, nutrients and proteins in order to make them available for proper crop growth and development.

- Crop production plays a crucial role in Nigeria's economy. It does provide food, raw materials, and employment. In modern times, marketing, processing, distribution and aftersales service are also accepted as parts of crop production. In places where the real income per capital is low, emphasis is being laid on crop production and other primary industries. It is seen that increased crop production output and productivity tend to contribute substantially to the overall economic development of a country. It will hence be appropriate to place greater emphasis on further crop production development.

- As agriculture struggles to support the rapidly growing population, plant diseases reduce crop production quantity and quality. Agricultural losses due to post-harvest diseases can be disastrous.

- Weeds consist one of the major threats to all agricultural activities. Weeds reduce farm and forest productivity, invade crops, smother pastures, and in some cases harm livestock. They aggressively compete with the crops for water, nutrients and sunlight, resulting in reduced crop yield and poor crop quality. 


\section{SOIL MANAGEMENT}

Soil management is an integral part of agricultural activities. A sound knowledge of various soil types and conditions will enhance crop yield and conserve soil resources. It is the use of operations, practices and treatments to improve soil performance. Urban soils may contain pollutants which can be investigated with a traditional soil survey approach [11]. The application of compost and manure improve soil porosity and aggregation. A better aggregation indicates the addition of organic materials that play an important role in preventing soil crust formation. It is possible to adopt alternative tillage systems to prevent soil physical degradation. The application of organic materials is essential to improve soil quality [12]. Production of vegetables and other edible crops is often significantly affected by several soil-borne pathogens that require control through soil management [13]. Sensitivity to soil degradation is implicit in the assessment of the sustainability of land management practices, with recognition of the fact that soils vary in their ability to resist change and recover [14].

A summary in AI soil management techniques is shown in Table I. Management-oriented modeling (MOM) minimizes nitrate leaching as it consists of a set of generated plausible management alternatives, a simulator that evaluates each alternative, and an evaluator that determines which alternative meets the user-weighted multiple criteria. MOM uses "hillclimbing" as a strategic search method that uses "best-first| as a tactical search method to find the shortest path from start nodes to goals [15]. Knowledge of engineering for constructing the Soil Risk Characterization Decision Support System (SRCDSS) involves three stages: knowledge acquisition, conceptual design and system implementation [16]. An artificial neural network (ANN) model predicts soil texture (sand, clay and silt contents) based on attributes obtained from existing coarse resolution soil maps combined with hydrographic parameters derived from a digital elevation model (DEM) [21]. The dynamics of soil moisture are characterized and estimated by a remote sensing device embedded in a higher-order neural network (HONN) [22].

\section{CROP MANAGEMENT}

The crop management techniques are summarized in Table II. Crop management starts with sowing, and continues with monitoring growth, harvesting, and crop storage and distribution. It is summarized as the activities that improve the growth and yield of agricultural products. In-depth understanding of class of crops according to their timing and thriving soil type will certainly increase crop yield. Precision crop management (PCM) is an agricultural management system designed to target crop and soil inputs according to field requirements to optimize profitability and protect the environment. PCM has been hampered by lack of timely, distributed information on crop and soil conditions [26]. Farmers must combine various crop management strategies to cope with water deficit resulting from soil, weather or limited irrigation. Flexible crop management systems based on decision rules should be preferred. Timing, intensity, and predictability of drought are important features for choosing among cropping alternatives [27].
TABLE I. AI IN SOIL MANAGEMENT SUMMARY

\begin{tabular}{|c|c|c|c|}
\hline Application & Technique & Strength & Limitation \\
\hline$[15]$ & MOM & $\begin{array}{l}\text { Minimizes nitrate } \\
\text { leaching, maximizes } \\
\text { production. }\end{array}$ & $\begin{array}{l}\text { Takes time. Limited } \\
\text { only to nitrogen. }\end{array}$ \\
\hline$[16]$ & $\begin{array}{l}\text { Fuzzy Logic: } \\
\text { SRC-DSS }\end{array}$ & $\begin{array}{c}\text { Can classify soil } \\
\text { according to associated } \\
\text { risks. }\end{array}$ & $\begin{array}{l}\text { Needs big data. } \\
\text { Only a few cases } \\
\text { were studied. }\end{array}$ \\
\hline$[17]$ & DSS & $\begin{array}{l}\text { Reduces erosion and } \\
\text { sedimentary yield. }\end{array}$ & $\begin{array}{l}\text { Requires big data } \\
\text { for training. }\end{array}$ \\
\hline$[18]$ & ANN & $\begin{array}{c}\text { Can predict soil } \\
\text { enzyme activity. } \\
\text { Accurately predicts and } \\
\text { classifies soil structure. }\end{array}$ & $\begin{array}{l}\text { Only measures a } \\
\text { few soil enzymes. It } \\
\text { considers more } \\
\text { classification than } \\
\text { improving the } \\
\text { performance of the } \\
\text { soil. }\end{array}$ \\
\hline [19] & ANN & $\begin{array}{l}\text { Can predict monthly } \\
\text { mean soil temperature }\end{array}$ & $\begin{array}{c}\text { Considers only } \\
\text { temperature as a } \\
\text { factor for soil } \\
\text { performance. }\end{array}$ \\
\hline$[20]$ & ANN & It predicts soil texture & $\begin{array}{l}\text { Requires big data } \\
\text { for training. Has } \\
\text { restriction in areas } \\
\text { of implementation. }\end{array}$ \\
\hline$[21]$ & ANN & $\begin{array}{l}\text { Able to predict soil } \\
\text { moisture. }\end{array}$ & $\begin{array}{l}\text { The prediction will } \\
\text { fail with time as } \\
\text { weather conditions } \\
\text { are hardly } \\
\text { predictable. }\end{array}$ \\
\hline$[22]$ & ANN & $\begin{array}{l}\text { Successfully reports } \\
\text { soil texture. }\end{array}$ & $\begin{array}{l}\text { It does not improve } \\
\text { soil texture or } \\
\text { proffers solution to } \\
\text { bad soil texture. }\end{array}$ \\
\hline$[23]$ & ANN & $\begin{array}{l}\text { Cost-effective, saves } \\
\text { time, has } 92 \% \text { accuracy }\end{array}$ & Requires big data. \\
\hline$[24]$ & ANN & $\begin{array}{c}\text { Can estimate soil } \\
\text { nutrients after erosion. }\end{array}$ & $\begin{array}{l}\text { Its estimate is } \\
\text { restricted to only } \\
\mathrm{NH}_{4} .\end{array}$ \\
\hline
\end{tabular}

Proper understanding of weather patterns helps in the decision-making process that will result in high and quality crop yield [28]. PROLOG utilizes weather data, machinery capacities, labor availability, and information on permissible and prioritized operators, tractors, and implements for evaluating the operational behavior of a farm system. It also estimates crop production, gross revenue, and net profit for individual fields and for the whole farm [30]. Crop prediction methodology is used to predict the suitable crop by sensing various soil parameters and parameter related to the atmosphere. Parameters like soil type, $\mathrm{PH}$, nitrogen, phosphate, potassium, organic carbon, calcium, magnesium, sulfur, manganese, copper, iron, depth, temperature, rainfall, humidity [31]. Demeter is a computer-controlled speed-rowing machine, equipped with a pair of video cameras and a global positioning sensor for navigation. It is capable of planning harvesting operations for an entire field, and then executing its plan by cutting crop rows, turning to cut successive rows, repositioning itself in the field, and detecting unexpected obstacles $\lceil 32\rceil$. The use of AI in harvesting cucumber comprises of the individual hardware and software components of the robot including the autonomous vehicle, the manipulator, the end-effector, the two computer vision systems for detection and 3D imaging of the fruit and the environment and, finally, a control scheme that generates 
collision-free motions for the manipulator during harvesting 「337. Field-specific rainfall data and weather variables can be used for each location. Adjusting ANN parameters affects the accuracy of rice yield predictions. Smaller data sets required fewer hidden nodes and lower learning rates in model optimization [38].

TABLE II. AI IN CROP MANAGEMENT SUMMARY

\begin{tabular}{|c|c|c|c|}
\hline Application & Technique & Strength & Limitation \\
\hline [29] & CALEX & $\begin{array}{c}\text { Can formulate } \\
\text { scheduling guidelines } \\
\text { for crop management } \\
\text { activities. }\end{array}$ & Takes time. \\
\hline$[30]$ & PROLOG & $\begin{array}{l}\text { Removes less used } \\
\text { farm tools from the } \\
\text { farm. }\end{array}$ & Location-specific. \\
\hline [31] & ANN & Predicts crop yeild. & $\begin{array}{c}\text { Only captures } \\
\text { weather as a factor } \\
\text { for crop yeild. }\end{array}$ \\
\hline$[32]$ & $\begin{array}{l}\text { ROBOTICS- } \\
\text { Demeter }\end{array}$ & $\begin{array}{l}\text { Can harvest up to } 40 \\
\text { hectares of crop }\end{array}$ & $\begin{array}{l}\text { Expensive: Uses a } \\
\text { lot of fuel. }\end{array}$ \\
\hline$[33]$ & ROBOTICS & $\begin{array}{l}\text { Has } 80 \% \text { success rate } \\
\text { in harvesting crops }\end{array}$ & $\begin{array}{c}\text { Slow picking speed } \\
\text { and accuracy. }\end{array}$ \\
\hline [34] & ANN & $\begin{array}{l}\text { Above } 90 \% \text { success } \\
\text { rate in detecting crop } \\
\text { nutrition disorder. }\end{array}$ & $\begin{array}{l}\text { A little number of } \\
\text { symptoms were } \\
\text { considered. }\end{array}$ \\
\hline$[35]$ & $\begin{array}{l}\text { FUZZY } \\
\text { Cognitive } \\
\text { Map }\end{array}$ & $\begin{array}{l}\text { Predict cotton yield and } \\
\text { improve crop for } \\
\text { decision management. }\end{array}$ & It is relatively slow. \\
\hline$[36]$ & ANN & $\begin{array}{l}\text { Can predict the } \\
\text { response of crops to } \\
\text { soil moisture and } \\
\text { salinity. }\end{array}$ & $\begin{array}{l}\text { Considers only soil } \\
\text { temperature and } \\
\text { texture as factors. }\end{array}$ \\
\hline$[37]$ & $\begin{array}{c}\text { ANN and } \\
\text { Fuzzy Logic }\end{array}$ & $\begin{array}{l}\text { Reduces insects that } \\
\text { attack crops. }\end{array}$ & $\begin{array}{l}\text { Shows inability to } \\
\text { differentiate } \\
\text { between crop and } \\
\text { weed. }\end{array}$ \\
\hline$[38]$ & ANN & $\begin{array}{l}\text { Can accurately predict } \\
\text { rice yield. }\end{array}$ & $\begin{array}{l}\text { Time-consuming, } \\
\text { limited to a } \\
\text { particular climate. }\end{array}$ \\
\hline
\end{tabular}

\section{DisEASE MANAGEMENT}

To have an optimal yield in agricultural harvest, disease control is necessary. Plant and animal diseases are a major limiting factor regarding the increase of yield. Several factors play role in the incubation of these diseases which attack plants and animals, which include genetic, soil type, rain, dry weather, wind, temperature, etc. Due to these factors and the unsteady nature of some diseases causative influence, managing the effects is a big challenge, especially in large scale farming. Table III lists the AI applications in disease management available in the literature. To effectively control diseases and minimize losses, a farmer should adopt an integrated disease control and management model that includes physical, chemical and biological measure [39]. To achieve these is time consuming and not at all that cost effective [40], hence the need for application of AI approach for disease control and management. Explanation block (EB) gives a clear view of the logic followed by the kernel of the expert system [42]. A novel approach of rule promotion based on fuzzy logic is used in the system for drawing intelligent inferences for crop disease management. A text-to-speech (TTS) converter is used for providing capability of text-to-talking user interface. It provides highly-effective interactive user interface on web for live interactions [45]. A rule based and forward chaining inference engine has been used for the development of the system that helps in detecting the diseases and provide treatment suggestion in [46].

TABLE III. AI IN DISEASE MANAGEMENT SUMMARY

\begin{tabular}{|c|c|c|c|}
\hline Application & Technique & Strength & Limitation \\
\hline$[42]$ & $\begin{array}{l}\text { Computer vision } \\
\text { system (CVS), } \\
\text { genetic algorithm } \\
\text { (GA), ANN }\end{array}$ & $\begin{array}{l}\text { Works at a high } \\
\text { speed. Can multi- } \\
\text { task. }\end{array}$ & $\begin{array}{l}\text { Dimension-based } \\
\text { detection which } \\
\text { may affect good } \\
\text { species. }\end{array}$ \\
\hline$[42]$ & $\begin{array}{c}\text { Rule-Based } \\
\text { Expert, Data } \\
\text { Base (DB) }\end{array}$ & $\begin{array}{c}\text { Accurate results in } \\
\text { the tested } \\
\text { environment. }\end{array}$ & $\begin{array}{c}\text { Inefficacy of DB } \\
\text { when implementing } \\
\text { in large scale. }\end{array}$ \\
\hline [43] & $\begin{array}{l}\text { Fuzzy Logic } \\
(\text { FL), Web GIS }\end{array}$ & $\begin{array}{l}\text { Cost effective, eco } \\
\text { friendly. }\end{array}$ & $\begin{array}{l}\text { Inefficiency due to } \\
\text { scattered } \\
\text { distribution. Takes } \\
\text { time to locate and } \\
\text { disperse data. The } \\
\text { location of the data } \\
\text { is determined by a } \\
\text { mobile browser. }\end{array}$ \\
\hline$[44]$ & $\begin{array}{l}\text { FL Web-Based, } \\
\text { Web-Based } \\
\text { Intelligent } \\
\text { Disease } \\
\text { Diagnosis } \\
\text { System } \\
\text { (WIDDS) } \\
\end{array}$ & $\begin{array}{l}\text { Good accuracy. } \\
\text { Responds swiftly to } \\
\text { the nature of crop } \\
\text { diseases. }\end{array}$ & $\begin{array}{l}\text { Limited usage as it } \\
\text { requires internet } \\
\text { service. Its potency } \\
\text { cannot be } \\
\text { ascertained as only } \\
4 \text { seed crops were } \\
\text { considered. }\end{array}$ \\
\hline$[45]$ & $\begin{array}{l}\text { FL \& TTS } \\
\text { converter }\end{array}$ & $\begin{array}{l}\text { Resolves plant } \\
\text { pathological } \\
\text { problems quickly. }\end{array}$ & $\begin{array}{l}\text { Requires high speed } \\
\text { internet. Uses a } \\
\text { voice service as its } \\
\text { multimedia } \\
\text { interface. }\end{array}$ \\
\hline$[46]$ & $\begin{array}{l}\text { Expert system } \\
\text { using rule-base } \\
\text { in disease } \\
\text { detection }\end{array}$ & $\begin{array}{c}\text { Faster treatment as } \\
\text { diseases are } \\
\text { diagnosed faster. } \\
\text { Cost effective } \\
\text { based on its } \\
\text { preventive } \\
\text { approach. } \\
\end{array}$ & $\begin{array}{l}\text { Time consuming. } \\
\text { Needs constant } \\
\text { monitoring to check } \\
\text { if pest has built } \\
\text { immunity to the } \\
\text { preventive measure. }\end{array}$ \\
\hline$[47]$ & ANN, GIS & $95 \%$ accuracy & $\begin{array}{c}\text { Internet-based. } \\
\text { Some rural farmers } \\
\text { will not have } \\
\text { access. }\end{array}$ \\
\hline$[48]$ & $\begin{array}{c}\text { FuzzyXpest } \\
\text { provides pest } \\
\text { information for } \\
\text { farmers. It is also } \\
\text { supported by } \\
\text { internet services. }\end{array}$ & $\begin{array}{l}\text { High precision in } \\
\text { forecast. }\end{array}$ & Internet dependent. \\
\hline [49] & $\begin{array}{c}\text { Web-Based } \\
\text { Expert System }\end{array}$ & High performance. & $\begin{array}{c}\text { Internet and web } \\
\text { based. }\end{array}$ \\
\hline$[50]$ & ANN & $\begin{array}{l}\text { Has above than } \\
90 \% \text { prediction } \\
\text { rate. }\end{array}$ & $\begin{array}{l}\text { The ANN does not } \\
\text { kill infections or } \\
\text { reduces its effect. }\end{array}$ \\
\hline
\end{tabular}

\section{WEED MANAGEMENT}

Weed consistently reduces the farmers' expected profit and yield [51]. A report confirms a 50\% reduction in yield for dried beans and corn crops if weed infestations are not controlled [51]. There is about $48 \%$ loss in wheat yield due to weed competition $[52,53]$. These losses may at times rise up to $60 \%$ [54]. A study on the impact of weed on Soybean showed about $8 \%-55 \%$ reduction in yield [55]. A study on yield losses in 
sesame crops accounts them to about 50\%-75\% [56]. The fluctuation in yield losses may be attributed to the length of exposure of the crops to the weeds [57, 58] and spatial heterogeneity of weeds [59]. Beyond these, weed has both positive and negative effects to the ecosystem. According to the relative Weed Science Society of America (WSSA) report, weed effects include flooding during hurricane, some species of weeds can pave their way during rampant fire, some cause irreparable liver damage if consumed, and they muscle out plants or crops by competing for water, nutrients and sunlight. Some weeds are poisonous and cause allergic reactions or even may threat public health. Table IV lists a summary of the AI in weed managements uses.

TABLE IV. AI IN WEED MANAGEMENT SUMMARY

\begin{tabular}{|c|c|c|c|}
\hline Application & Technique & Strength & Limitation \\
\hline$[61]$ & ANN, GA & $\begin{array}{c}\text { High } \\
\text { performance. } \\
\text { Reduces trial and } \\
\text { error. }\end{array}$ & Requires big data. \\
\hline$[62]$ & $\begin{array}{c}\text { Optimization } \\
\text { using invasive } \\
\text { weed } \\
\text { optimization } \\
\text { (IVO), ANN }\end{array}$ & $\begin{array}{l}\text { Cost effective, } \\
\text { enhanced } \\
\text { performance. }\end{array}$ & $\begin{array}{l}\text { Adaptation } \\
\text { challenge with } \\
\text { new data. }\end{array}$ \\
\hline [63]. & $\begin{array}{c}\text { Mechanical } \\
\text { Control of Weeds. } \\
\text { ROBOTICS. } \\
\text { Sensor machine } \\
\text { learning } \\
\end{array}$ & $\begin{array}{l}\text { Saves time and } \\
\text { removes resistant } \\
\text { weeds. }\end{array}$ & $\begin{array}{c}\text { Expensive. } \\
\text { Constant use of } \\
\text { heavy machine } \\
\text { will reduce soil } \\
\text { productivity. }\end{array}$ \\
\hline$[64]$ & UAV, GA & $\begin{array}{l}\text { Can quickly and } \\
\text { efficiently } \\
\text { monitor weeds. }\end{array}$ & $\begin{array}{l}\text { Has little or no } \\
\text { control on weeds. } \\
\text { Expensive. }\end{array}$ \\
\hline$[65]$ & $\begin{array}{l}\text { Saloma expert } \\
\text { system for } \\
\text { evaluation, } \\
\text { prediction \& } \\
\text { weed } \\
\text { management. }\end{array}$ & $\begin{array}{l}\text { High adaptation } \\
\text { rate and } \\
\text { prediction level. }\end{array}$ & $\begin{array}{l}\text { Requires big data } \\
\text { and usage } \\
\text { expertise. }\end{array}$ \\
\hline$[66]$ & $\begin{array}{c}\text { Support Vector } \\
\text { Machine (SVM), } \\
\text { ANN }\end{array}$ & $\begin{array}{l}\text { Quickly detects } \\
\text { stress in crop that } \\
\text { will prompt } \\
\text { timely site-- } \\
\text { specific remedies. }\end{array}$ & $\begin{array}{l}\text { Only detects low } \\
\text { levels of nitrogen. }\end{array}$ \\
\hline$[67]$ & $\begin{array}{c}\text { Digital Image } \\
\text { Analysis (DIA), } \\
\text { GPS }\end{array}$ & $\begin{array}{c}\text { Has above } 60 \% \\
\text { accuracy and } \\
\text { success rate. }\end{array}$ & $\begin{array}{c}\text { Its success was } \\
\text { achieved after } 4 \\
\text { years and as such, } \\
\text { it is really time } \\
\text { consuming. }\end{array}$ \\
\hline [68] & UAV & $\begin{array}{l}\text { High rate of weed } \\
\text { detection within a } \\
\text { short period of } \\
\text { time. }\end{array}$ & $\begin{array}{c}\text { It is really } \\
\text { expensive and } \\
\text { requires vast } \\
\text { human expertise. }\end{array}$ \\
\hline [69] & $\begin{array}{c}\text { Learning Vector } \\
\text { Quantization } \\
\text { (LVQ), ANN }\end{array}$ & $\begin{array}{l}\text { High weed } \\
\text { recognition rate } \\
\text { with short } \\
\text { processing time. }\end{array}$ & $\begin{array}{l}\text { The method of } \\
\text { data input used } \\
\text { affected the AI's } \\
\text { perfromance. }\end{array}$ \\
\hline
\end{tabular}

An intensive management with herbicides has been deployed over the past decades to reduce its effect on crops. However, even with this management pattern, it was predicted that crop losses due to weed in western Canada field crops are estimated to exceed $\$ 500$ million annually [60], hence the need for a more expert weed management technique to compensate for this loss emerges [51]. A system can utilize an unmanned aerial vehicle (UAV) -imagery to divide image, compute and convert to binary the vegetation indexes, detect crop rows, optimize parameters and learn a classification model. Since crops are usually organized in rows, the use of a crop row detection algorithm helps to separate properly weed and crop pixels, which is a common handicap given the spectral similitude of both [64]. Weed control in sugar-beet, maize, winter wheat, and winter barley, can be done by applying online weed detection using digital image analysis taken by an UAV (drone), computer-based decision making and global positioning system (GPS)-controlled patch spraying [67]. The drone in [68] travelled at a speed of $1.2 \mathrm{~km} / \mathrm{h}$, with $58.10 \mathrm{~ms}$ and $37.44 \mathrm{~ms}$ execution time to find the tomato and weed locations to the spray controller respectively

\section{CURTAILING CHALLENGES OF AI IN AGRICULTURE}

Expert systems are tools for agricultural management since they can provide site-specific, integrated, and interpreted advices. However, the development of expert systems for agriculture is fairly recent, and the use of these systems in commercial agriculture is rare to date [70]. Although AI has made some remarkable improvement in the agricultural sector, it still has a below the average impact on the agricultural activities when compared to its potentials and impacts in other sectors. More still need to be done to improve agricultural activities using $\mathrm{AI}$ as there are many limitations to its implementation.

\section{A. Limitation: Response Time and Accuracy}

A major attribute of an intelligent or expert system is its ability to execute tasks accurately in very short time. Most of the systems fall short either in response time or accuracy, or even both. A system delay affects a user's selection of task strategy. Strategy selection is hypothesized to be based on a cost function combining two factors: (1) the effort required to synchronize input system availability, and (2) the accuracy level afforded. People seeking to minimize effort and maximize accuracy, choose among three strategies: automatic performance, pacing, and monitoring [71].

\section{B. Limitation 2: Big Data Required}

The strength of an intelligent agent is also measured on the volume of input data. A real-time AI system needs to monitor an immense volume of data. The system must filter out much of the incoming data. However, it must remain responsive to important or unexpected events [72]. An in-depth knowledge of the task of the system is required from a field expert and only very relevant data should be used improving the system's speed and accuracy. The development of an agricultural expert system requires the combined efforts of specialists from many fields of agriculture, and must be developed with the cooperation of the growers who will use them [70].

\section{Limitation 3: Method of Implementation}

The beauty of any expert system lies on its execution methodology. Since it uses big data, the method of looking-up and training should be properly defined for speed and accuracy.

\section{Limitation 4: High Data Cost}

Most AI systems are internet-based which in turn reduces or restricts their usage, particularly in remote or rural areas. 
The government can support farmers by designing a web service enabling device with lower tariff to uniquely work with the AI systems for farmers. Also, a form of "how to use" orientation (training and re-training) will really help farmers adapt to the use of AI on the farm.

\section{E. Limitation 5: Flexibility}

Flexibility is a strong attribute of any sound AI system. It is perceived that much progress has been made in applying AI techniques to particular isolated tasks, but the important theme at the leading edge of the AI-based robotics technology seems to be the interfacing of the subsystems into an integrated environment. This requires flexibility of the subsystems themselves [73]. It should also have expansive capabilities to accommodate more user data from the field expert.

\section{THE FUTURE OF AI IN AGRICULTURE}

Global population is expected to reach more than nine billions by 2050 which will require an increase in agricultural production by $70 \%$ in order to fulfil the demand. Only about $10 \%$ of this increased production may come from unused lands and the rest should be fulfilled by current production intensification. In this context, the use of latest technological solutions to make farming more efficient remains one great necessity. Present strategies to intensify agricultural production require high energy inputs and market demands high quality food. [74]. Robotics and autonomous systems (RAS) are set to transform global industries. These technologies will have great impact on large sectors of the economy with relatively low productivity such as agro-food (food production from the farm to the retail shelf). The UK agro-food chain generates over $£ 108$ bn p.a., with $3.7 \mathrm{~m}$ employees in a truly international industry yielding $£ 20 \mathrm{bn}$ of exports in 2016 [75].

\section{REFERENCES}

[1] M. A. Kekane, "Indian agriculture-status, importance and role in Indian economy", International Journal of Agriculture and Food Science Technology, Vol. 4, No. 4, pp. 343-346, 2013

[2] B. F. Johnston, P. Kilby, Agriculture and Structural Transformation: Economic Strategies in Late-Developing Countries, Oxford University Press, 1975

[3] S. Kuznets, "Modern economic growth: Findings and reflections", American Economic Association, Vol. 63, No. 3, pp. 247-258, 1973

[4] M. Syrquin, "Patterns on Structural Change", in: Handbook of Development Economics, Vol. 1, Elsevier, 1988

[5] R. Dekle, G. Vandenbroucke, "A quantitative analysis of China's structural transformation", Journal of Economic Dynamics and Control, Vol. 36, No. 1, pp. 119-135, 2012

[6] M. Fan, J. Shen, L. Yuan, R. Jiang, X. Chen, W. J. Davies, F. Zhang, "Improving crop productivity and resource use efficiency to ensure food security and environmental quality in China", Journal of Experimental Botany, Vol. 63, No. 1, pp. 13-24, 2012

[7] O. Oyakhilomen, R. G. Zibah, "Agricultural production and economic growth in Nigeria: Implication for rural poverty alleviation", Quarterly Journal of International Agriculture, Vol. 53, No. 3, pp. 207-223, 2014

[8] T. O. Awokuse, "Does Agriculture Really Matter for Economic Growth in Developing Countries?", The American Agricultural Economics Association Annual Meeting, Milwaukee, Newark, USA, July 28, 2009

[9] O. Badiene, Sustaining and Accelerating Africa's Agricultural Growth Recovery in the Context of Changing Global Food Prices, IFPRI Policy Brief 9, 2008
[10] S. Block, C. Timmer, Agriculture and Economic Growth: Conceptual Issues and the Kenyan Experience, Harvard Institute for International Development, 1994

[11] C. R. D. Kimpe, J. L. Morel, "Urban soil management: A growing concern", Soil Science, Vol. 165, No. 1, pp. 31-40, 2000

[12] M. Pagliai, N. Vignozzi, S. Pellegrini, "Soil structure and the effect of management practices", Soil and Tillage Research, Vol. 79, No. 2, pp. 131-143, 2004

[13] G. S. Abawi, T. L. Widmer, "Impact of soil health management practices on soilborne pathogens, nematodes and root diseases of vegetable crops", Applied Soil Ecology, Vol. 15, No. 1, pp. 37-47, 2000

[14] J. K. Syers, Managing Soil for Long-Term Productivity, The Royal Society, 1997

[15] M. Li, R. Yost, "Management-oriented modelling: Optimizing nitrogen management with artificial intelligence", Agricultural Systems, Vol. 65, No. 1, pp. 1-27, 2000

[16] E. M. Lopez, M. Garcia, M. Schuhmacher, J. L. Domingo, “A fuzzy expert system for soil characterization", Environment International, Vol. 34, No. 7, pp. 950-958, 2008

[17] H. Montas, C. A. Madramootoo, “A Decision Support System for Soil Conservation Planning", Computers and Electronics in Agriculture, Vol. 7, No. 3, pp. 187-202, 1992

[18] S. Tajik, S. Ayoubi, F. Nourbakhsh, "Prediction of soil enzymes activity by digital terrain analysis: Comparing artificial neural network and multiple linear regression models", Environmental Engineering Science, Vol. 29, No. 8, pp. 798-806, 2012

[19] E. R. Levine, D. S. Kimes, V. G. Sigillito, "Classifying soil structure using neural networks", Ecological Modelling, Vol. 92, No. 1, pp. 101108,1996

[20] M. Bilgili, "The use of artificial neural network for forecasting the monthly mean soil temperature in Adana, Turkey", Turkish Journal of Agriculture and Forestry, Vol. 35, No. 1, pp. 83-93, 2011

[21] Z. Zhao, T. L. Chow, H. W. Rees, Q. Yang, Z. Xing, F. R. Meng, "Predict soil texture distributions using an artificial neural network model", Computers and Electronics in Agriculture, Vol. 65, No. 1, pp. 36-48, 2009

[22] A. Elshorbagy, K. Parasuraman, "On the relevance of using artificial neural networks for estimating soil moisture content", Journal of Hydrology, Vol. 362, No. 1-2, pp. 1-18, 2008

[23] D. H. Chang, S. Islam, "Estimation of soil physical properties using remote sensing and artificial neural network", Remote Sensing of Enviroment, Vol. 74, No. 3, pp. 534-544, 2000

[24] T. Behrens, H. Forster, T. Scholten, U. Steinrucken, E. D. Spies, M. Goldschmitt, "Digital soil mapping using artificial neural networks", Journal of Plant Nutrition and Soil Science, Vol. 168, No. 1, pp. 21-33, 2005

[25] M. Kim, J. E. Gilley, “Artificial neural network estimation of soil erosion and nutrient concentrations in runoff from land application areas", Computers and Electronics in Agriculture, Vol. 64, No. 2, pp. 268-275, 2008

[26] M. S. Moran, Y. Inoue, E. M. Barnes, "Opportunities and limitations for image-based remote sensing in precision crop management", Remote Sensing of Enviroment, Vol. 61, No. 3, pp. 319-346, 1997

[27] P. Debaeke, A. Aboudrare, "Adaptation of crop management to waterlimited environments", European Journal of Agronomy, Vol. 21, No. 4, pp. 433-446, 2004

[28] C. Aubry, F. Papy, A. Capillon, "Modelling decision-making processes for annual crop management", Agricultural Systems, Vol. 56, No. 1, pp. 45-65, 1998

[29] R. E. Plant, "An artificial intelligence based method for scheduling crop management actions", Agricultural Systems, Vol. 31, No. 1, pp. 127155,1989

[30] H. Lal, J. W. Jones, R. M. Peart, W. D. Shoup, "FARMSYS-A wholefarm machinery management decision support system", Agricultural Systems, Vol. 38, No. 3, pp. 257-273, 1992

[31] S. S. Snehal, S. V. Sandeep, "Agricultural crop yield prediction using artificial neural network approach", International Journal of Innovative 
Research in Electrical, Electronics, Instrumentation and Control Engineering, Vol. 2, No. 1, pp. 683-686, 2014

[32] T. Pilarski, M. Happold, H. Pangels, M. Ollis, K. Fitzpatrick, A. Stentz, The Demeter System for Automated Harvesting, Springer, 2002

[33] E. J. V. Henten, J. Hemming, B. A. J. V. Tuijl, J. G. Kornet, J. Meuleman, J. Bontsema, E. A. V. Os, An Autonomous Robot for Harvesting Cucumbers in Greenhouses, Springer, 2002

[34] H. Song, Y. He, "Crop Nutrition Diagnosis Expert System Based on Artificial Neural Networks", 3rd International Conference on Information Technology and Applications, Sydney, Australia, July 4-7, 2005

[35] E. I. Papageorgiou, A. T. Markinos, T. A. Gemtos, "Fuzzy cognitive map based approach for predicting crop production as a basis for decision support system in precision agriculture application", Applied Soft Computing, Vol. 11, No. 4, pp. 3643-3657, 2011

[36] X. Dai, Z. Huo, H. Wang, "Simulation of response of crop yield to soil moisture and salinity with artificial neural network", Field Crops Research, Vol. 121, No. 3, pp. 441-449, 2011

[37] C. C. Yang, S. O. Prasher, J. A. Landry, H. S. Ramaswamy, "Development of herbicide application map using artificial neural network and fuzzy logic", Agricultural Systems, Vol. 76, No. 2, pp. 561574, 2003

[38] B. Ji, Y. Sun, S. Yang, J. Wan, “Artificial neural networks for rice yield prediction in mountainous regions", Journal of Agricultural Science, Vol. 145, No. 3, pp. 249-261, 2007

[39] BEA, Value Added by Industry as a Percentage of Gross Domestic Product, available at: https://apps.bea.gov/iTable/iTable.cfm?ReqID=51 \&step $=1$ \#reqid $=51 \&$ step $=51 \&$ isuri $=1 \& 5114=\mathrm{a} \& 5102=5,2018$

[40] Weed Science Society of America, Facts About Weeds, available at: http://wssa.net/wp-content/uploads/WSSA-Fact-SheetFinal.pdf

[41] J. Fang, C. Zhang, S. Wang, "Application of Genetic Algorithm (GA) Trained Artificial Neural Network to Identify Tomatoes with Physiological Diseases", International Conference on Computer and Computing Technologies in Agriculture, Wuyishan, China, August 1820, 2007

[42] K. Balleda, D. Satyanvesh, N. V. S. S. P. Sampath, K. T. N. Varma, P. K. Baruah, "Agpest: An Efficient Rule-Based Expert System to Prevent Pest Diseases of Rice \& Wheat Crops", 8th International Conference on Intelligent Systems and Control, Coimbatore, India, January 10-11, 2014

[43] J. Jesus, T. Panagopoulos, A. Neves, "Fuzzy Logic and Geographic Information Systems for Pest Control in Olive Culture", 4th IASME/WSEAS International Conference on Energy, Environment, Ecosystems \& Sustainable Development, Algarve, Portugal, June 11-13, 2008

[44] S. Kolhe, R. Kamal, H. S. Saini, G. K. Gupta, “A web-based intelligent disease-diagnosis system using a new fuzzy-logic based approach for drawing the interferences in crops", Computers and Electronics in Agriculture, Vol. 76, No. 1, pp. 16-27, 2011

[45] S. Kolhe, R. Kamal, H. S. Saini, G. K. Gupta, "An intelligent multimedia interface for fuzzy-logic based inference in crops", Expert Systems with Applications, Vol. 38, No. 12, pp. 14592-14601, 2011

[46] M. Y. Munirah, M. Rozlini, Y. M. Siti, “An Expert System Development: Its Application on Diagnosing Oyster Mushroom Diseases", 13th International Conference on Control, Automation and Systems, Gwangju, South Korea, October 20-23, 2013

[47] G. Liu, X. Yang, Y. Ge, Y. Miao, “An Artificial Neural Network-Based Expert System for Fruit Tree Disease and Insect Pest Diagnosis", International Conference on Networking, Sensing and Control, Lauderdale, USA, April 23-25, 2006

[48] F. Siraj, N. Arbaiy, "Integrated Pest Management System Using Fuzzy Expert System", Knowledge Management International Conference \& Exhibition, Kuala Lumpur, Malaysia, June 6-8, 2006

[49] P. Virparia, "A Web Based Fuzzy Expert System for Insect Pest Management in Groundnut Crop 'Prajna", Journal Of Pure \& Applied Sciences, Vol. 15, pp. 36-41, 2007
[50] X. Wang, M. Zhang, J. Zhu, S. Geng, "Spectral prediction of phytophthora infestans infection on tomatoes using artificial neural network", International Journal of Remote Sensing, Vol. 29, No. 6, pp. 1693-1706, 2006

[51] K. N. Harker, "Survey of yield losses due to weeds in central Alberta", Canadian Journal of Plant Science, Vol. 81, No. 2, pp. 339-342, 2001

[52] M. Khan, N. Haq, "Wheat crop yield loss assessment due to weeds", National Agricultural Research Cen intensification tre, Vol. 18, No. 4, pp. 449-453, 2002

[53] S. Fahad, S. Hussain, B. S. Chauhan, S. Saud, C. Wu, S. Hassan, M. Tanveer, A. Jan, J. Huang, "Weed growth and crop yield loss in wheat as influenced by row spacing and weed emergence times", Crop Protection, Vol. 71, pp. 101-108, 2015

[54] A. N. Rao, S. P. Wani, J. K. Ladha, Weed Management Research in India-An Analysis of the Past and Outlook for Future, ICAR, 2014

[55] A. Datta, H. Ullah, N. Tursun, T. Pornprom, S. Z. Knezevic, B. S. Chauhan, "Managing weeds using crop competition in soybean [Glycine $\max ($ L.) Merr.]", Crop Protection, Vol. 95, pp. 60-68, 2017

[56] T. Mruthul, Chemical weed management in sesame (Sesamum indicum L.), MSc Thesis, College of Agriculture, Raichur, University of Agricultural Sciences, 2015

[57] C. J. Swanton, R. Nkoa, R. E. Blackshaw, "Experimental methods for crop-weed competition studies", Weed Science Society of America, Vol. 63, No. 1, pp. 2-11, 2015

[58] P. Jha, V. Kumar, R. K. Godara, B. S. Chauhan, "Weed management using crop competition in the United States: A Review", Crop Protection, Vol. 95, pp. 31-37, 2017

[59] P. Milberg, E. Hallgren, "Yield loss due to weeds in cereals and its large-scale variability in Sweden", Field Crops Research, Vol. 86, No. 2-3, pp. 199-209, 2004

[60] C. J. Swanton, K. N. Harker, R. L. Anderson, "Crop losses due to weeds in Canada", Weed Technology, Vol. 7, No. 2, pp. 537-542, 1993

[61] A. M. Tobal, S. A. Mokhtar, "Weeds identification using evolutionary artificial intelligence algorithm", Journal of Computer Science, Vol. 10, No. 8, pp. 1355-1361, 2014

[62] P. Moallem, N. Razmjooy, “A multi-layer perception neural network trained by invasive weed optimization for potato color image segmentation", Trends in Applied Sciences Research, Vol. 7, No. 6, pp. 445-455, 2012

[63] M. Brazeau, "Fighting Weeds: Can we Reduce, or Even Eliminate, Herbicides by Utilizing Robotics and AI", available at: https:/geneticliteracyproject.org/2018/12/12/fighting-weeds-can-wereduce-or-even-eliminate-herbicide-use-through-robotics-and-ai/, 2018

[64] M. P. Ortiz, P. A. Gutierrez, J. M. Pena, J. T. Sanchez, F. L. Granados, C. H. Martinez, "Machine Learning Paradigms for Weed Mapping Via Unmanned Aerial Vehicles", Symposium Series on Computational Intelligence, Athens, Greece, December 6-9, 2016

[65] L. Stigliani, C. Resina, "Seloma: Expert system for weed management in herbicide-intensive crops", Weed Technology, Vol. 7, No. 3, pp. 550559,1993

[66] Y. Karimi, S. O. Prasher, R. M. Patel, S. H. Kim, “Application of support vector machine technology for weed and nitrogen stress detection in corn", Computers and Electronics in Agriculture, Vol. 51, No. 1-2, pp. 99-109, 2006

[67] R. Gerhards, S. Christensen, "Real-time weed detection, decisionmaking and patch-spraying in maize, sugarbeet, winter wheat and winter barley”, Wiley Online Library, Vol. 43, No. 6, pp. 385-392, 2003

[68] F. L. Granados, "Weed detection for site-specific weed management: Mapping and real-time approaches", Weed Research, Vol. 51, No. 1, pp. $1-11,2011$

[69] C. C. Yang, S. O. Prasher, J. Laundry, H. S. Ramaswamy, "Development of neural networks for weed recognition in corn fields", American Society of Agricultural and Biological Engineers, Vol. 45, No. 3, pp. 859-864, 2002

[70] E. G. Rajotte, T. Bowser, J. W. Travis, R. M. Crassweller, W. Musser, D. Laughland, C. Sachs, "Implementation and Adoption of an Agricultural Expert System: The Penn State Apple Orchard Consultant", 
in: International Symposium on Computer Modelling in Fruit Research and Orchard Management, ISHS, 1992

[71] S. L. Teal, A. I. Rudnicky, "A Performance Model of System Delay and User Strategy Selection", Conference on Human Factors in Computing Systems, California, USA, May 3-7, 1992

[72] R. Washington, B. H. Roth, "Input Data Management in Real-Time AI System", 11th International Joint Conference on Artificial Intelligence, Michigan, USA, August 20-25, 1989

[73] P. Mowforth, I. Bratko, AI and Robotics: Flexibility and Integration, Cambridge University Press, 1987

[74] D. G. Panpatte, Artificial Intelligence in Agriculture: An Emerging Era of Research, Anand Agricultural University, 2018

[75] T. Duckett, S. Pearson, S. Blackmore, B. Grieve, Agricultural Robotics: The Future of Robotic Agriculture, UK-RAS, 2018 